\title{
ZAŁOŻENIA FENOMENOLOGICZNE I KONSTRUKTYWISTYCZNE JAKO PODSTAWY TEORII KOMUNIKACJI W SOCJOLOGII RELIGII
}

We współczesnej socjologii, w tym również w obszarze socjologii religii, współistnieje wiele założeń teoretycznych, przedstawiających i interpretujących rzeczywistość społeczną z różnych perspektyw częściowo komplementarnych, częściowo zaś wykluczających się nawzajem. W toku rozwoju społecznego, wraz z pojawiającymi się wciąż nowymi tendencjami kulturowymi, popularność zyskują koncepcje niekoniecznie będące nowością samą w sobie, ale na danym etapie rozwoju społecznego nadające się szczególnie do wyjaśniania zjawisk zachodzących w poszczególnych obszarach społecznej rzeczywistości. W ramach analiz teoretycznych i badań empirycznych w ciągu ostatnich lat coraz częściej wskazuje się na możliwość podjęcia próby stworzenia ogólnej teorii religii w oparciu o teorię komunikacji.

Celem niniejszego artykułu będzie przedstawienie wybranych wątków myśli socjologicznej i filozoficznej, które przyczyniły się do powstania orientacji komunikacyjnej w socjologii religii, od klasycznego ujęcia Maxa Webera, poprzez założenia fenomenologiczne i konstruktywistyczne, aż do obecnej postaci tej koncepcji, rozwijanej przez współczesnych badaczy. Komunikacyjna teoria religii jest wciąż koncepcją in statu nascendi. Wiąże ze sobą jednak duże nadzieje socjologów, którzy w niej właśnie upatrują możliwości wyjaśniania współczesnych zjawisk religijnych $\mathrm{w}$ oparciu o nową perspektywę, bardziej przydatną do rozpoznawania i interpretowania szczególnie tych form religijności lub duchowości, które do tej pory włączane były do obszaru zainteresowań socjologii religii rzadko lub wcale.

\footnotetext{
* Dr Agnieszka Zduniak - socjolog, adiunkt Katedry Socjologii Uniwersytetu Warmińsko-Mazurskiego w Olsztynie
} 


\section{PUNKT WYJŚCIA TEORII KOMUNIKACYJNEJ: \\ WEBEROWSKIE VERSTEHEN I FENOMENOLOGIA}

Źródeł dowartościowania procesu komunikacji w teorii socjologicznej można dopatrywać się już w rozważaniach Maxa Webera, który za konieczną podstawę badań nad życiem społecznym uznał analizę ludzkiego działania jako zachowania, któremu jednostka przypisuje sens motywacyjny możliwy do odczytania również przez tych, ku którym skierowane jest jej społeczne działanie. Zadaniem socjologii jest rekonstruowanie tego subiektywnego sensu. Poglądy Webera można określić jako metodologiczny indywidualizm lub ujęcie subiektywistyczne: działanie społeczne nie może być zrozumiane bez odniesienia do działających jednostek.

W tej perspektywie religia, rozumiana jako forma ludzkiego działania społecznego, wymaga określonych działań podejmowanych wraz z innymi i w odniesieniu do innych. Są to działania znaczące; o tym, jaki sens przypisują im jednostki, decydują ich dotychczasowe doświadczenia, przeżycia oraz cele, jakie pragną osiągnąć, dlatego też ich znajomość jest niezbędna do prawidłowego zinterpretowania działań o charakterze religijnym. W takim ujęciu religia staje się narzędziem interpretacji i kształtowania rzeczywistości ${ }^{1}$.

Do stworzonej przez Maxa Webera kategorii działania społecznego, czyli zawierającego w sobie sens motywacyjny i skierowanego ku innym, nawiązuje Alfred Schütz, wprowadzając pojęcie sensu obiektywnego. Wskazuje tym samym na niezwykle istotną z socjologicznego punktu widzenia kwestię, jaką jest powstawanie w toku życia społecznego zasad, reguł i strategii postępowania, które pozwalają jednostce poszukiwać sensu podejmowanych przez siebie działań nie za każdym razem w toku indywidualnej refleksji, ale odwołując się do istniejących już w kulturze gotowych modeli zachowań, działań i reakcji emocjonalnych przypisanych do określonych sytuacji społecznych. Jednostka nadaje więc sens swoim działaniom umieszczając je niejako w gotowym kontekście kulturowym, stanowiącym wspólny horyzont odniesienia wszystkich, z którymi wchodzi w interakcje ${ }^{2}$.

Sens, który ludzie przypisują działaniom swoim i innych, Schütz analizuje z fenomenologicznego punktu widzenia: kluczowe znaczenie mają tu procesy zachodzące w świadomości działających jednostek, a rozumienie sensu ludzkich działań jest możliwe poprzez odwołanie do pojęcia intencjonalności. Podobnie jak Weber, uważa, że działanie społeczne to działanie ukierunkowane na innych, przy czym ci ,inni” nie muszą być (choć jednak najczęściej są) ludźmi. W takim ujęciu działanie społeczne może więc odnosić się również do istot nadprzyrodzonych (bóstwa, duchy), osób wyobrażonych, a nawet do przedmiotów, którym w procesie

${ }^{1}$ I. Mörth, Die gesellschaftliche Wirklichkeit von Religion. Grundlegung einer allgemeinen Religionstheorie, Stuttgart 1978, s. 17.

2 A. Schütz, Der sinnhafte Aufbau der sozialen Welt, Wien 1960, s. 40 nn. 
antropomorfizacji mogą być przypisywane właściwości ludzkie. Działanie społeczne ma charakter zwrotny: wiąże się z antycypowaną, a najczęściej również rzeczywistą odpowiedzią tych, ku którym zostało skierowane. Na przykład dla osoby zadającej komuś pytanie czynność ta stanowi działanie, z którym związana jest motywacja „po to, aby”. Wiąże się ona z pewnym projektem działania, w ramach którego osoba działająca przewiduje jakiś cel, który chce osiągnąć, a który nie musi być wcale jasny dla osoby, która $\mathrm{w}$ reakcji na zadane pytanie ma udzielić odpowiedzi (a więc podjąć działnie recyprokalne). Jednak sam fakt, że pytanie padło, wytwarza u jego adresata motywację do udzielenia odpowiedzi. Ta motywacja, określana jako „dlatego, że", stanowi inny typ motywacji niż ten występujący u osoby inicjującej interakcję, ale z perspektywy adresata wyznacza ona sens jego działania (odpowiedzi na pytanie). Stanowi ona dla niego wystarczającą motywację do włączenia się $\mathrm{w}$ proces komunikowania, choć jego własne, subiektywnie projektowane cele nie odgrywają $\mathrm{w}$ tym przypadku roli.

Ogół ludzkich działań składa się na kluczowy wymiar rzeczywistości społecznej, jakim jest „świat życia codziennego". W jego ramach powstaje struktura społecznej rzeczywistości, a jego składnikami są ludzkie działania zmierzające do przekształcania otoczenia materialnego (czyny), zwrotnego oddziaływania na innych ludzi (interakcje) oraz procesy komunikowania. Świat codzienności w przekonaniu Schütza ma charakter dominujący nad innymi obszarami życia społecznego; jest tak nie tylko dlatego, że przeważają w nim motywacje pragmatyczne i „czyny”, czyli konkretne działania ludzi zmierzające do wywierania wpływu na otoczenie, ale przede wszystkim dlatego, że właśnie w sferze codzienności ma miejsce komunikacja z innymi. Podkreślanie ważności komunikacji w życiu społecznym sprawia, że to właśnie Alfred Schütz uchodzi za protagonistę zwrotu komunikacyjnego w socjologii.

Recyprokalny charakter komunikacji sprawia, że dla jej zaistnienia i niezakłóconego przebiegu niezwykle istotny jest konsens co do znaczenia znaków i symboli wykorzystywanych w jej przebiegu. Udana komunikacja może zachodzić jedynie między osobami, grupami i większymi zbiorowościami, które odwołują się do takich samych lub przynajmniej istotnie podobnych systemów znaczeń i schematów interpretacyjnych ${ }^{3}$. Język stanowi najważniejszy nośnik i medium, za pomocą którego przekazywane są zobiektywizowane w danej społeczności zasoby wiedzy tak, aby mogły być przyswojone, zaakceptowane i zinternalizowane przez jednostki, i żeby mogły w przyszłości stanowić punkty odniesienia ukierunkowujące jeśli nie w całkowitym, to przynajmniej w znaczącym stopniu ich działania podejmowane w życiu codziennym.

Znaki i symbole odgrywają szczególnie istotną rolę w procesie komunikowania doświadczeń związanych ze sferą transcendencji. Posługiwanie się nimi umożliwia

3 A. Schütz, Symbol, Wirklichkeit und Gesellschaft, w: tenże, Gesammelte Aufsätze, Band 1: Das Problem der sozialen Wirklichkeit, Den Haag: Nijhoff 1971, s. 372 nn. 
zdolność ludzkiego umysłu do aprezentacji, czyli łączenia ze sobą w świadomości dwóch zjawisk, z których jedno (znak) wskazuje na inne (doświadczenie, zjawisko, stan rzeczy). Znaki mogą oznaczać przedmioty, wydarzenia, ale również działania, motywacje i intencje. Podczas gdy znaki odnoszą się do elementów rzeczywistości stanowiących świat codziennych doświadczeń, to symbole wskazują na doświadczenia transcendujące codzienną rzeczywistość ${ }^{4}$.

Właśnie dzięki komunikacji zachodzącej za pośrednictwem znaków i symboli może nastepować proces intersubiektywnego konstruowania społecznej rzeczywistości, będący głównym obszarem zainteresowania socjologii fenomenologicznej. Jej zwolennicy wychodzą z założenia, że leżące u podstaw działań jednostek przekonania, poglądy i oczekiwania, a także sposoby oceniania i wartościowania określonych zdarzeń lub zjawisk, powstają nie tylko w sferze indywidualnej, lecz również w kontekście intersubiektywnym. Przestrzenią tworzenia się rzeczywistości społecznej jest więc obszar interakcji między jednostkami i grupami. W toku tych interakcji oddziałują one na siebie, a rezultatem takiego oddziaływania jest wzajemne uzgadnianie swoich postaw, oczekiwań i działań ${ }^{5}$ Powstaje w ten sposób wspólny, intersubiektywny obszar społecznej rzeczywistości (zwany również wspólną definicją sytuacji), na który składa się podzielana przez wszystkich wiedza oraz wspólnota doświadczenia.

Założenia socjologii fenomenologicznej, w szczególności jej koncentracja na takich elementach życia społecznego jak proces nadawania znaczeń leżący u podstaw projektowania ludzkich działań, kwestia ich intencjonalności, sposób interpretowania przez jednostki sytuacji społecznych i tworzenia zasad regulujących ich zachowanie i interakcje z innymi, mogą znaleźć zastosowanie nie tylko w analizie codziennego świata doświadczeń jednostki, lecz również w analizach religijnosocjologicznych. Wprawdzie na bazie założeń fenomenologicznych trudno byłoby sformułować ogólną teorię religii, jednak taki punkt widzenia pozwala na wyjaśnienie wielu zjawisk religijnych istotnych w perspektywie współczesności. Może on na przykład stanowić punkt wyjścia do poszukiwania odpowiedzi na pytanie o to, w jaki sposób indywidualistycznie zorientowane jednostki tworzą wspólny świat znaczeń odnoszących się do ostatecznych spraw ludzkiej egzystencji, a także w jakim stopniu ten wspólny horyzont znaczeń wpływa na sferę indywidualnego doświadczenia religijnego.

${ }^{4}$ H. Knoblauch, Transzendenzerfahrung und symbolische Kommunikation. Die phänomenologisch orientierte Soziologie und die kommunikative Konstruktion der Religion, w: H. Tyrell, V. Krech, H. Knoblauch (Hg.), Religion als Kommunikation, Würzburg 1998, s. 164.

5 J. Matthes, Handlungstheoretisch - interaktionistisch - phänomenologisch orientierte Theorie, w: R. Lepsius (Hg.), Zwischenbilanz der Soziologie, Stuttgart 1976, s. 53. 


\section{KONSTRUKTYWIZM SOCJOLOGICZNY I „ZWROT KOMUNIKACYJNY”}

W nurt socjologii fenomenologicznej wpisują się poglądy Petera L. Bergera i Thomasa Luckmanna, którzy jednak odchodzą w pewnym stopniu od fenomenologicznej analizy konstytuowania świata społecznego poprzez akty świadomości na rzecz podkreślania sposobów konstruowania rzeczywistości społecznej przez społeczne działanie. Widać tu wyraźne przesunięcie od fenomenologicznego do stricte socjologicznego punktu widzenia. Podczas gdy fenomenologia rekonstruowała genezę subiektywnego sensu w świadomości jednostki, konstrukcja w ujęciu Bergera i Luckmanna oznacza wytwarzanie struktur społecznych poprzez społeczne działania podejmowane przez wielu aktorów. Działanie społeczne ma postać interakcji, w których dochodzi do powstawania nie tylko wzorów działania w określonych sytuacjach społecznych, lecz również wzorów interpretacji o charakterze intersubiektywnym (a więc konstruowania rzeczywistości społecznej). W takim konstruktywistycznym ujęciu opis działania społecznego koncentruje się już nie na indywidualnym, jednostkowym projekcie działania, lecz na interakcji ${ }^{6}$.

Perspektywa konstruktywistyczna kładzie nacisk na powstawanie w procesach interakcji instytucji społecznych i systemów wiedzy, a więc utrwalonych struktur, które również poprzez interakcje są podtrzymywane lub modyfikowane. Instytucje takie są społecznie legitymizowane, to znaczy wiążą się z nimi określone struktury znaczeń, które mogą mieć charakter pragmatyczny lub symboliczny. W procesie socjalizacji jednostka przyswaja sobie zarówno wzory zachowań przypisane do określonej sytuacji, jak również wzory ich interpretacji, czyli sens, jaki jest im przypisany. Wpływa to w znaczący sposób na kształtowanie jej tożsamości, na przykład poprzez przejmowanie określonych ról społecznych i identyfikowanie się z nimi.

Tożsamość jednostki w takim ujęciu jest więc konstrukcją społeczną, a nie produktem jednostkowej świadomości. Decydujący wpływ na jej kształtowanie i podtrzymywanie wywiera zachodzący w społeczeństwie proces komunikowania. To, co pozornie wydaje się indywidualnym sensem działania podejmowanego przez jednostkę, a więc jej zamiary i projekty, na ogół nie stanowi wytworu indywidualnego, ale jest owocem wyboru dokonanego spośród niezliczonych, gotowych już systemów znaczeń, instrukcji działania i życiowych projektów stanowiących zasoby wiedzy danej społeczności. To one tak naprawdę sterują działaniami jednostek, określają ich sens i strukturę oraz koordynują je z pozostałymi działaniami tej samej jednostki oraz innych jednostek i grup. „Ta różnorodność powstaje w długich łańcuchach procesów komunikowania [...] Indywidualne i kolektywne doświadczenia oraz sposoby rozwiązywania problemów ludzkiego działania i orientacji w świecie stają

${ }^{6}$ H. Knoblauch, B. Schnettler, Vom sinnhaften Aufbau zur kommunikativen Konstruktion, in: M. Gabriel (Hg.), Paradigmen akteurszentrierter Soziologie, Wiesbaden 2004, s. 127. 
się przedmiotem opowieści i raportów, poezji i mitów [...] W procesie społecznego rekonstruowania wyników intersubiektywnych procesów komunikacji powstaje „rzeczywistość'- świat, który zyskuje trwały status ontologiczny”7.

Konstruowanie społecznej rzeczywistości dokonuje się poprzez dialektykę trzech procesów: eksternalizacji - czyli artykułowania subiektywnych doświadczeń i znaczeń, obiektywizacji - procesu przetwarzania tego, co wyartykułowane, w rzeczywistość dostępną również dla innych, a więc we „wspólny świat znaczeń”, oraz internalizacji - przyswajania przez jednostkę tego, co zostało już społecznie zobiektywizowane. W ten sposób ustanowiony zostaje społeczny porządek znaczeń (nomos). W jego ramach porządkowane są i systematyzowane ludzkie doświadczenia. Procesy te są możliwe wówczas, gdy jednostki uczestniczące w życiu społecznym dysponują wspólnym repertuarem znaków, dzięki któremu mogą nawzajem komunikować sobie swoje doświadczenia, obserwacje i stany psychiczne. Szczególną rolę w tym procesie odgrywa język (dzięki któremu konstruowany jest i przekazywany społeczny zasób wiedzy), a także religia, pełniąca funkcję stabilizującą dzięki odnoszeniu porządku społecznego do świętego kosmosu, co zapobiega zagrożeniu chaosem i poczuciem bezsensu.

Definicja religii Luckmanna ma charakter antropologiczny: religia to przekraczanie ograniczeń, transcendowanie ludzkiej, biologicznej natury. Może to następować na trzy zasadnicze sposoby, stąd też postulat rozróżnienia trzech poziomów transcendencji. Małe transcendencje to po prostu przekraczanie ograniczeń przestrzennych i czasowych; średnie transcendencje obejmują już doświadczenia dostępne tylko pośrednio, jak na przykład doświadczenie inności, odmienności drugiego człowieka; wielkie transcendencje stanowią natomiast sferę doświadczeń wykraczających poza sferę życia codziennego. Religia jest społecznie uznaną, zinstytucjonalizowaną formą obchodzenia się ze szczególnym rodzajem doświadczeń odnoszących się do „wielkich transcendencji”, a więc takich, które są odbierane jako niesamowite, tajemnicze, budzące lęk lub przeciwnie - poczucie głębokiego zachwytu i szczęścia. Ich źródłem mogą być ostateczne problemy ludzkiej egzystencji, ale również sny i wizje, doznania mistyczne i ekstatyczne. Jeżeli to, co wykracza poza ramy codzienności, nie ma pozostać wyłącznym doświadczeniem jednostki, lecz ma zostać zakomunikowane innym, musi zostać wyrażone za pomocą znaków i symboli, które będą zrozumiałe dla potencjalnych odbiorców takiego komunikatu, a więc będą odnosić się do znanych im przekonań, poglądów i wyobrażeń. Religia jest więc zobiektywizowanym systemem symbolicznym (symbolicznym uniwersum) ${ }^{8}$.

Tak rozumiana religia pełni rolę czynnika umożliwiającego konstruowanie elementarnego sensu świata i rzeczywistości społecznej. Składają się na nią in-

${ }^{7}$ T. Luckmann, Der kommunikative Aufbau der sozialen Welt und die Sozialwissenschaften, w: tenże, Wissen und Gesellschaft. Ausgewählte Aufsätze 1981-2002, Konstanz 2002, s. 157.

${ }^{8}$ P. L. Berger, T. Luckmann, Społeczne tworzenie rzeczywistości. Traktat z socjologii wiedzy, Warszawa 2010. 
tersubiektywnie podzielane wyobrażenia oraz wiedza biorąca swój początek od subiektywnego doświadczenia transcendencji, które następnie podlega procesom intersubiektywnego rekonstruowania, aż do uzyskania społecznie uznanego statusu ontologicznego. Dokonuje się to w procesie komunikowania, w trakcie którego indywidualne doświadczenia transcendencji zostają zobiektywizowane i uformowane za pomocą typizacji i schematów interpretacyjnych. Utrwalanie religii w społecznej świadomości następuje między innymi poprzez ustalenia dogmatyczne i regulacje dotyczące sposobów sprawowania określonych rytuałów, umieszczenie w kontekście określonych tradycji czy instytucji.

Luckmann nie wypowiada się jednoznacznie co do tego, które z wymienionych przez niego form transcendencji mogą stać się przestrzenią doświadczenia religijnego. W jego pismach można znaleźć tezę, że każda $\mathrm{z}$ form transcendencji, to znaczy zarówno małe, średnie, jak i wielkie, mogą stać się podstawą religijnych symbolizacji, ale również i tezę, że za religijne należy uznać tylko te elementy rzeczywistości społecznej, które mają swoje korzenie w doświadczeniach transcendencji o charakterze niecodziennym, wskazujących na rzeczywistość odmienną od świata codziennych doświadczeń . To drugie rozróżnienie z perspektywy badawczej wydaje się zdecydowanie bardziej użyteczne, ponieważ założenie, że wszystkie rodzaje transcendencji mogą potencjalnie generować doświadczenie religijne, prowadziłoby do możliwości uznania za religijne wszystkich subiektywnych doświadczeń. Ograniczenie sfery doświadczeń religijnych wyłącznie do sfery wielkich transcendencji jest zgodne z poglądami Alfreda Schütza, dla którego charakterystyczną cechą religii jest to, że odróżnia się ona od sfery życia codziennego ${ }^{10}$. Jednak nie wszystko, co odmienne od świata codziennych doświadczeń, jest religią. Doświadczenia wielkich transcendencji mogą przybierać formy również doświadczeń natury estetycznej lub teoretyczno-naukowej.

Proces konstruowania rzeczywistości symbolicznej w toku komunikacji następuje nie jedno- lecz dwukierunkowo. Indywidualne doświadczenia transcendencji dostarczają niejako materiału - tworzywa, które może stać się budulcem społecznie zobiektywizowanych rzeczywistości symbolicznych. Ale zależność ta działa również w drugą stronę: to, co jednostka rekonstruuje w swojej świadomości i komunikuje innym jako indywidualne doświadczenie, podlega modyfikacji i formowaniu poprzez społecznie uznane wyobrażenia, modele i wzorce. Chociaż doświadczenie religijne ma z zasady charakter subiektywny i często określa się je jako niemożliwe do komunikowania, to jednak obecne w społeczeństwie schematy interpretacyjne wpływają W znaczącym stopniu na konstruowanie i rekonstrukcję takiego doświadczenia w świadomości jednostki. Rekonstrukcja ta ma na ogół charakter nieświadomy:

${ }^{9}$ H. Knoblauch, Transzendenzerfahrung und symbolische Kommunikation, s. 155, por. T. Luckmann, Über die Funktion der Religion, w: P. Koslowski (Hg.), Die religiöse Dimension der Gesellschaft. Religion und ihre Theorien, Tübingen 1985, s. 35.

10 A. Schütz, Über die mannigfaltigen Wirklichkeiten, w: Gesammelte Aufsätze Bd. 1, den Haag 1971, s. 237-295. 
jednostka przyswaja sobie (zapamiętuje i czyni możliwym do zakomunikowania) te elementy doświadczenia, które w takim czy innym stopniu ,pasują” do schematów i wyobrażeń obecnych już wcześniej w społeczności, której jest członkiem ${ }^{11}$.

Luckmann poświęca dużo uwagi utrwalonym formom komunikacji (gatunkom komunikacyjnym). Są to reguły przypisujące pewne zachowania komunikacyjne do konkretnych sytuacji społecznych i nadające im określoną strukturę. Istnieją oczywiście w życiu społecznym sytuacje, w których reguły te nie są ściśle określone, na przykład w ramach codziennych, nieformalnych interakcji. Stosowanie się do reguł, nawet jeśli dana sytuacja tego wymaga, zależy też od poszczególnych jednostek, które mogą dostosowywać się do nich w większym lub mniejszym stopniu (a w niektórych przypadkach również całkowicie je odrzucić). Istnieją jednak sytuacje, w których formy komunikowania są ściśle określone, a nawet sformalizowane, umożliwiając rozwiązywanie typowych, powtarzających się problemów komunikacyjnych w oparciu o znane, gotowe schematy, do których można się odwołać.

Gatunki komunikacyjne mają charakter częściowo zinstytucjonalizowany, to znaczy, nieprzestrzeganie pewnych reguł określających, jak w danej sytuacji powinna przebiegać komunikacja, może pociągnąć za sobą sankcje albo przynajmniej doprowadzić do zakłócenia procesu komunikacji ${ }^{12}$. O tym, jaki gatunek i jakie konkretnie elementy zostaną zastosowane, decyduje nie tylko sytuacja społeczna, ale również wiele innych czynników: status, ranga uczestników, ich przynależność do określonej warstwy społecznej, role, jakie w danej sytuacji przyjmują, repertuar językowy i stylistyczny danego wzorca komunikacji, składający się typowe połączenie typowych przewidzianych elementów. Obecność takich wzorów nie tylko determinuje działanie komunikacyjne, lecz również wpływa na interpretację tego, co zostało zakomunikowane ${ }^{13}$.

Wzory i gatunki komunikacji związane są z określonymi środowiskami różniącymi się pod względem etnicznym, zawodowym, wiekowym, płciowym. W ramach takich środowisk tworzą się często również zorganizowane, a nawet sformalizowane grupy, stowarzyszenia i organizacje wyróżniające się określoną tematyką i stylem komunikacji. Jej specyficzne formy pojawiają się również w kontekście instytucji życia społecznego: prawnych, ekonomicznych, pedagogicznych, wojskowych, religijnych itp. Szczególnym przypadkiem zinstytucjonalizowanej komunikacji są instytucje religijne. Charakterystyczne jest dla nich przywiązanie do określonych form wyrazu, takich jak modlitwy, kazania, chorały, ale również zaklęcia czy cisza medytacyjna. Istotną rolę odgrywają przy tym pozawerbalne środki komunikacji, takie jak taniec sakralny, procesje, święte obrazy itp ${ }^{14}$.

${ }^{11}$ T. Luckmann, Niewidzialna religia. Problem religii w nowoczesnym społeczeństwie, przeł. L. Bluszcz, Kraków 2011, s. 148 nn.

${ }^{12}$ Szczegółowe badania na ten temat przeprowadził w latach 60-tych Harold Garfinkel, patrz:

H. Garfinkel, Studia z etnometodologii, przeł. A. Szulżycka, Warszawa 2007, s. $52 \mathrm{nn}$.

13 T. Luckmann, Der kommunikative Aufbau der sozialen Welt, s. 164.

14 Tamże, s. 198. 
Społeczny konstruktywizm, przedstawiony w pracach Bergera i Luckmanna, można określić jako próbę wypracowania swoistego kompromisu między założeniem o istnieniu obiektywnie doświadczalnej rzeczywistości a stwierdzeniem, że społeczne regulacje i instytucje są tworzone (konstruowane) przez ludzi w toku społecznych interakcji. Stanowi on ważny etap kształtowania się teorii komunikacyjnej przede wszystkim dzięki szczególnie silnemu zaakcentowaniu roli komunikacji w życiu społecznym, w tym również w sferze religii. W analizach tych społeczeństwo zyskuje dwojaki charakter: stanowi połączenie subiektywnych sensów i obiektywnych znaczeń. Takie ujęcie może się okazać bardzo cenne z perspektywy wymagań, jakim musi stawić czoło współczesna socjologia religii, bo pozwala na ukazanie dialektyki przenikania się indywidualnego i społecznego wymiaru religijności oraz roli, jaką w tym zakresie może odegrać komunikacja religijna. Jest ona daleko czymś więcej niż tylko medium służącym do komunikowania treści religijnych, ponieważ sama je współtworzy i selekcjonuje.

\section{RADYKALNY KONSTRUKTYWIZM W TEORII KOMUNIKACJI I W SOCJOLOGII}

Konstruktywizm w teorii komunikacji został rozwinięty poprzez prace Paula Watzlawicka, Janet Beavin Bavelas i Dona D. Jacksona. Ich koncepcja stanowi jego radykalną wersję: wszystko, co ludzie uznają za rzeczywistość, jest w rzeczywistości konstruowane przez tych, którzy ją obserwują, badają czy odkrywają. Ludzkie próby zrozumienia i poznania świata poprzez własną obserwację i doświadczenie tylko na pozór mają charakter wolny, odkrywczy i niczym nieograniczony. W rzeczywistości doświadczenia te maja charakter z góry ustrukturowany, ponieważ integralną częścią życia społecznego są różnego rodzaju porządki, które ułatwiają jednostce zrozumienie świata i interpretację własnych doświadczeń i przeżyć. Nie to, co doświadczone, zaobserwowane czy odkryte tworzy rzeczywistość, lecz to, co zostało skonstruowane, pozornie na podstawie własnych doświadczeń, w rzeczywistości jednak w toku uzgadniania ich znaczenia z innymi podmiotami życia społecznego. Komunikując się z innymi, jednostka dopasowuje swoje doświadczenia do obrazu świata społeczności, której jest częścią: do społecznie uznanych poglądów, przekonań i wyobrażeń ${ }^{15}$. Można więc stwierdzić, że rzeczywistość nie jest czymś obiektywnie danym, lecz zależnym od subiektywnego punktu widzenia, na który składają się doświadczenia jednostki oraz wiedza, której źródłem jest jej otoczenie społeczne.

\footnotetext{
${ }^{15}$ P. Watzlawick, J. Beavin, D. D. Jackson, Pragmatics of human communication, New York 1967.
} 
Na gruncie socjologii teza o kluczowym znaczeniu procesu komunikacji w życiu społecznym zostaje podjęta przez niemieckiego socjologa Niklasa Luhmanna, zyskując również w jego ujęciu postać zaskakująco radykalną. Konstruktywistyczno-komunikacyjne założenia Luhmanna sprowadzają rzeczywistość społeczną wyłącznie do komunikacji, z pominięciem jednostek i ich świadomości. Pojęcie komunikacji łączy się ściśle z pojęciem dyskursu. To nie podmiot tworzy komunikację, lecz przeciwnie: jest wytworem komunikacji, czy według innych ujęć - dyskursu. Powstaje w ten sposób bezosobowa wizja społeczeństwa jako wyłącznie systemu komunikacyjnego. Rzeczywistość społeczna nie jest więc tworem podmiotów, lecz składa się z niezależnych od nich procesów komunikacyjnych. Ponieważ to komunikacja tworzy społeczeństwo, nie stanowi ono w ujęciu Luhmanna struktury, którą można by podzielić na mikrostruktury (np. grupy); jedyna możliwość jego różnicowania to różnicowanie ze względu na odmienne typy komunikacji i związane z nimi semantyki.

Poszukując odpowiedzi na pytanie zadane już przez George’a Simmla: „Jak jest możliwe społeczeństwo?" Luhmann formułuje program oparty na kontrowersyjnym pojęciu radykalnego antyhumanizmu oraz radykalnie rozumianej konstruktywistycznej koncepcji społeczeństwa ${ }^{16}$. Mówiąc o antyhumanizmie, nie ma jednak na myśli negacji człowieczeństwa jako takiego, lecz jedynie założenie, że nie można wyjaśnić zjawisk społecznych, czyli powstawania i trwania społeczeństwa, odwołując się wyłącznie do jednostek - ich świadomości działań czy doświadczeń, sfery psychiki. Odcina się w ten sposób od poglądów Webera, który postrzegał jednak społeczeństwo przez pryzmat działań jednostkowych i przypisywanego im sensu. Nie da się, zdaniem Luhmanna, analizować łącznie systemów psychicznego i społecznego, lecz każdy z nich musi być rozpatrywany jako całość sui generis. Choć medium obu systemów jest sens, to każdy z nich konstruuje go inaczej: system psychiczny poprzez procesy poznawcze, system społeczny dzięki komunikacji17.

W koncepcji Luhmanna komunikacja porządkowana jest przez kody, czyli schematy różnicujące o charakterze binarnym, pełniące rolę selektywną wobec bodźców napływających do systemu i wskazujące, w jaki sposób system winien na nie reagować. Kod pozwala na określenie, jakie elementy należą do danego systemu, jakie zaś nie. Istotą komunikacji jest konstytuowanie różnic, czyli opisywanie zjawisk za pomocą binarnych kategorii. W ten sposób poszczególne zjawiska zostają oznaczone jako znane lub nieznane, zaufane lub nie. Komunikacja religijna jest sposobem obchodzenia się z tym, co nieznane i nie budzące zaufania poprzez przezwyciężenie binarnego podziału rzeczywistości i przekształcenie nieokreśloności w określoność sensu: „Religia jest próbą poradzenia sobie z tym

16 N. Luhmann, Die Gesellschaft der Gesellschaft, Frankfurt am Main 1999, s. 35.

${ }^{17} \mathrm{~S}$. Mandes, Miejsce religii w społeczeństwie. W poszukiwaniu nowego programu badawczego socjologii religii, Warszawa 2016, s. 237. 
podziałem, ujęcia tego, co budzi nieufność, co nieznane i nieoswojone, w ramy tego, co znane i co budzi zaufanie"18.

Religia jest więc również systemem komunikacyjnym, który dzięki charakterystycznej dla siebie semantyce opartej na rozróżnieniu transcendencja - immanencja, jest w stanie spełniać wobec systemu społecznego funkcję przezwyciężania kontyngencji poprzez nadawanie sensu temu, co nieokreślone, przypadkowe i niedysponowalne. Nieprzejrzystość życia społecznego, trudne do zaakceptowania zjawiska i wydarzenia, takie jak śmierć, cierpienie, grzech, doświadczenie niesprawiedliwości, niespełnienia i porażki, zyskują sens poprzez odniesienie do wyższej rzeczywistości. To, co nieokreślone i niezrozumiałe, zamienia się w sensowne ${ }^{19}$.

Dla Luhmanna komunikacja religijna ma jednak charakter paradoksalny. Religia jest bowiem próbą obserwacji tego, co nieobserwowalne. Sens istnienia wszechświata czy też wola Boża pozostaną i tak nieznane, niezależnie od tego, jak wiele zostanie powiedziane na ich temat. Religia jest komunikacją na temat sensu i on właśnie stanowi jej centrum, ale zadaniem komunikacji religijnej nie jest bynajmniej rozstrzyganie tego, co jest sensowne, co zaś nie, ani też pouczanie w kategoriach moralnych o tym, na czym polegać ma dobre życie. Chociaż takie treści również w niej występują, to ich obecność można tłumaczyć jedynie skutkami powiązania systemu religijnego z formami społecznej komunikacji w jego otoczeniu, nie zaś właściwościami samego systemu religijnego. Co ciekawe, dla Luhmanna istotą komunikacji religijnej nie jest też jej tematyka: mówienie o Bogu czy zbawieniu stanowi jedynie rodzaj szyfru włączającego w proces komunikowaia to, co w rzeczywistości niekomunikowalne. To, co najważniejsze w religijnej komunikacji, to sens: oferuje ona możliwość odnajdywania „sensu czegokolwiek”, a więc równowagi i spokoju we wszelkich sytuacjach życiowych, szczególnie tych trudnych do zaakceptowania. W zależności od wyznawanej religii, ideologii czy filozofii, sens można odnajdywać w miłości Boga do ludzi, w zjednoczeniu z wszechświatem albo w oderwaniu się od świata i jego spraw ${ }^{20}$.

Radykalizm i wysoki stopień abstrakcji poglądów Luhmanna sprawiają, że choć wielu badaczy odnosi się do nich w różnych aspektach swoich analiz, to zwykle odniesienia te mają charakter cząstkowy i wybiórczy, trudno natomiast byłoby wskazać nurt socjologiczny stanowiący kontynuację czy też rozwinięcie jego koncepcji w sposób całościowy. Jednak te często kontrowersyjne sformułowania i tezy w dużym stopniu inspirują, wyznaczając kierunki współczesnych dyskusji nie tylko ogólnosocjologicznych, lecz również w obszarze socjologii religii. Kontrowersje może z pewnością budzić pomijanie aspektu indywidualnej świadomości i redukcja podmiotu do roli wytworu komunikacji. Wątpliwości wywołuje teza,

18 Tamże, s. 260-261.

19 J. Campbell, Potęga mitu. Rozmowy Billa Moyersa z Josephem Campbellem, Kraków 2007, s. 23.

${ }^{20}$ N. Luhmann, Vom Sinn religiöser Kommunikation, w: K. Gabriel, A. Herlth, K. P. Strohmeier, Modernität und Solidarität. Konsequenzen gesellschaftlicher Modernisierung. Für Franz-Xaver Kaufmann, Freiburg in Breisgau 1997, s. 171-172. 
że systemy, w tym również religijny, nie zmieniają swoich zasadniczych właściwości pod wpływem otoczenia społecznego (innych systemów). Natomiast na przykład umieszczenie religii $\mathrm{w}$ kontekście swoistego rezerwuaru sensu znajduje na ogół uznanie w środowisku socjologów i doczekała się licznych nawiązań, chociażby w kontekście prób określenia, na czym w zglobalizowanym społeczeństwie mogłoby opierać się budowanie ogólnoświatowego etosu ${ }^{21}$. Koncepcja komunikacji jako procesu porządkowanego przez kody binarne może również stać się podstawą do przyszłych prób wytyczenia granic (rozróżnień) między komunikacją religijną a innymi formami komunikacji w sytuacji, gdy przywilej definiowania tego, co religijne, utraciły instytucje będące społecznymi reprezentantami religii.

\section{WSPÓŁCZESNY KONSTRUKTYWIZM KOMUNIKACYJNY W SOCJOLOGII - WYBRANE PRZYKLADY}

Nawiązanie do poglądów Bergera i Luckmanna, koncepcji Watzlawicka oraz poglądów Luhmanna stanowi współczesny socjologiczny nurt komunikatywnego konstruktywizmu. Program ten nie jest po prostu kontynuacją założeń konstruktywistycznych, lecz próbą adaptacji tych założeń do celów badań empirycznych. Chodzi tu o badania o charakterze jakościowym, co wynika z założeń metodologicznych programu. Jego punktem odniesienia są także teoretyczne rozważania Schütza, które zostają jednak na nowo zinterpretowane na potrzeby badań empirycznych. Program nawiązuje do tradycji weberowskiej, a w szczególności do stwierdzenia, że istotą życia społecznego jest działanie społeczne i dostosowywanie się działających jednostek do siebie nawzajem. W oparciu o te założenia komunikacyjny konstruktywizm przyjmuje, że wszystko, co jest istotne w działaniu społecznym, musi stać się przedmiotem komunikowania. Działanie społeczne może stać się przedmiotem doświadczenia innych osób (a więc zostać zobiektywizowane, stając się częścią społecznej rzeczywistości) dopiero wówczas, gdy stanie się przedmiotem komunikacji z innymi ${ }^{22}$.

Pojęcie komunikatywnego działania, jedno z podstawowych pojęć komunikatywnego konstruktywizmu, zostało zaczerpnięte od Jürgena Habermasa, jednak rozumiane jest nieco inaczej niż w jego teorii. Dla Habermasa działanie

${ }^{21}$ Np. J. Mariański, Megatrendy religijne w społeczeństwach ponowoczesnych. Studium socjologiczne, Toruń 2016, s. 247 nn; H. Küng, Projekt Weltethos, München 1990; S. P. Huntington, Zderzenie cywilizacji i nowy kształt ładu światowego, przeł. H. Jankowska, Kraków 1997, s. 67.

${ }^{22}$ H. Knoblauch, Grundbegriffe und Aufgaben des kommunikativen Konstruktivismus, Manuskriptfassung des Textes in: R. Keller, H. Knoblauch, J. Reichertz (Hg.), Kommunikativer Konstruktivismus. Theoretische und empirische Arbeiten zu einem neuen wissenssoziologischen Ansatz, Wiesbaden, s. 3. 
komunikatywne, ukierunkowane na porozumiewanie się z innymi, stanowiło odrębną kategorię, możliwą do odróżnienia od działania strategicznego o charakterze instrumentalnym, ukierunkowanego na realizację określonego celu. „W działaniach komunikacyjnych uczestnicy interakcji realizują swe plany działania w warunkach porozumienia osiąnniętego w drodze komunikacji, podczas gdy same koordynowane działania zachowują charakter działalności celowej”"23.

Charakterystyczną cechą działań komunikacyjnych - w odróżnieniu od strategicznych, instrumentalnych - jest istniejąca $\mathrm{w}$ ich przypadku możliwość ich podważenia, czyli zaprzeczenia im, a także uzasadnienia takiego zaprzeczenia. Możliwość taka wynika z „komunikacyjnej racjonalności”, której podlega proces komunikacji, a konkretnie z roszczeń do ważności, które zawiera w sobie każdy akt językowy. Habermas wyróżnia trzy kategorie takich roszczeń. Pierwsza z nich opiera się na stosunku tego, co zostało powiedziane, do świata obiektywnego (kryterium prawdziwości). Drugie odnosi się do zgodności wypowiedzi z kontekstem normatywnym (kryterium słuszności), trzecie zaś obejmuje adekwatność aktu mowy do wyrażenia wewnętrznych przeżyć, poglądów i intencji jednostki (kryterium szczerości). Pewną słabością teorii Habermasa jest to, iż odnosi się ona zasadniczo do aktów językowych, pomijając wiele innych nośników treści wykorzystywanych w działaniach komunikacyjnych, na przykład niewerbalne formy komunikowania mimikę, gestykulację, postawę ciała a także komunikację następującą przy użyciu znaków, obrazów i symboli oraz różnego rodzaju przedmiotów materialnych.

Jednym ze współczesnych przedstawicieli komunikacyjnego konstruktywizmu jest niemiecki socjolog Hubert Knoblauch. Przejmując od Habermasa pojęcie działania komunikacyjnego, jednocześnie kwestionuje on zasadność ścisłego podziału na działania komunikacyjne i instrumentalne. Działanie komunikacyjne jest bowiem zawsze również działaniem instrumentalnym, ponieważ łączy się z wytwarzaniem znaków: „Niezależnie od tego, czy chodzi o ręcznie napisany list, którego litery muszą zostać uformowane za pomocą atramentu, czy o dźwięk wytworzony mechanicznie za pomocą ust, czy o techniczną wizualizację na ekranie komputera, sporządzoną ręcznie na klawiaturze lub wgraną automatycznie: wszystkie przypadki działania komunikacyjnego zawierają w sobie działanie o charakterze instrumentalnym" ${ }^{24}$.

To, co staje się udziałem świadomości jednostkowej, może być komunikowane innym. Dotyczy to również przeżyć i doświadczeń o charakterze religijnym. Wpływ procesu komunikowania doświadczenia religijnego na jego status w świadomości jednostki może być interpretowany trojako. Pierwszy model interpretacyjny łączy się z przekonaniem o centralnym i decydującym charakterze samego doświadczenia, wobec którego komunikacja stanowi jedynie medium - nośnik umożliwiający przekazanie go innym i dostarczający koniecznych ku temu środków wyrazu.

${ }^{23}$ J. Habermas, Pojęcie działania komunikacyjnego, „Kultura i Społeczeństwo” 1986, nr 3, s. 42.

${ }^{24}$ H. Knoblauch, Grundbegriffe und Aufgaben des kommunikativen Konstruktivismus, s. 5. 
W takim modelu komunikacja ma pozycję drugorzędną; liczy się przede wszystkim doświadczenie jako takie, które pozostaje niezmienne bez względu na to, czy jednostka, której udziałem się stało, chciała podzielić się nim z innymi, czy też nie. Zakłada się więc, że proces komunikowania nie wpływa w żadnym stopniu na treść samego doświadczenia, samo z siebie nie może go zmieniać ani modyfikować. Łatwo zauważyć, że założenie takie łączy się z substancjalnymi ujęciami religii.

Drugi model interpretacyjny zakłada, że proces komunikowania doświadczenia może jednak w pewnym stopniu wpłynąć na to, jak będzie je postrzegać i interpretować jednostka, której udziałem się stało. Jest to model dialektyczny, a jego punkt wyjścia stanowi założenie, że doświadczenie i komunikacja warunkują się nawzajem. To, co zostało powiedziane, zależy od tego, co jednostka przeżyła i czego doświadczyła. Zależność ta jest jednak dwukierunkowa: językowa obiektywizacja przeżycia, dokonująca się w procesie jego komunikowania innym, oddziałuje zwrotnie na samo przeżycie, sprawiając, że jednostka postrzega je w określonych kategoriach (czasowych, przestrzennych), zalicza do określonych typów (przeżycie religijne lub np. psychologiczne), nadaje mu określoną strukturę poprzez wyartykułowanie pewnych przekonań, które później oddziałują na proces jego pamięciowej rekonstrukcji.

Trzeci model interpretacyjny, który nazwać można stricte komunikacyjnym, ponieważ właśnie proces komunikowania odgrywa w nim zasadniczą rolę, łączy się z założeniem, że doświadczenie religijne jest ściśle powiązane z kulturą społeczności, w jakiej żyje jednostka doświadczająca, jest więc niejako uzależnione od funkcjonujących w niej form komunikacji. „To, co ludzie odbierają jako religijne, zależy w dużej mierze od tego, co uchodzi za religijne w danej kulturze. Środki komunikacji, jakie oferuje kultura, są zgodnie z tym założeniem konstytutywne dla rodzaju, treści i statusu subiektywnych doświadczeń. Nie musi to oczywiście oznaczać, że ludzie doświadczają tylko takich przeżyć religijnych, które są możliwe do zakomunikowania. Jednakże religią (lub przedmiotem interpretacji w kategoriach religijnych) mogą stać się tylko takie doświadczenia, dla wyrażenia których istnieją formy językowe i wzory komunikacji”25.

Przykładem formy komunikacji, która może być zaliczona do komunikacji typowo religijnej, są świadectwa nawrócenia (konwersji). Bernd Ulmer wskazuje, że stanowią one specyficzny gatunek relacji biograficznej, która posiada ściśle określoną strukturę. Pierwszą jej część stanowi zawsze relacja z życia jednostki przed nawróceniem. Życie to jest przedstawiane w kategoriach błądzenia, bezskutecznego poszukiwania sensu, często też osoba przyznaje się do popełniania rozmaitych czynów, których obecnie się wstydzi. Przeszłość jest oceniana jako nieudany, często też nieszczęśliwy etap życia. Podkreśla się szczególnie te momenty, w których jednostka potrzebowała pomocy (kierownictwa), ale albo go nie otrzymała, albo też nie była W stanie lub nie chciała z niego skorzystać. Następnie relacja prowadzi do punktu

${ }^{25}$ H. Knoblauch, Religionssoziologie, Berlin - New York 1999, s. 198. 
kulminacyjnego, jakim jest moment nawrócenia. Zwykle jest ono przedstawiane jako wydarzenie o charakterze nadprzyrodzonym, zdecydowanie odbiegające od świata codziennych doświadczeń. Jednostka potrafi bardzo dokładnie określić ten moment i zwykle też podejmuje próbę opisania go, choć często zaznacza się tu, że chodzi o przeżycie niemożliwe do przełożenia na język codziennego doświadczenia, właśnie ze względu na jego niecodzienny charakter. $Z$ relacji wynika, że moment nawrócenia był głębokim, często wręcz wstrząsającym doświadczeniem emocjonalnym, które jednak jest wartościowane bardzo pozytywnie: jako rodzaj katharsis, oczyszczenia z błędów dawnego życia. Moment ten stanowi zasadniczy przełom w biografii jednostki, tak istotny, że całe życie postrzegane jest jako podzielone na dwa zasadnicze etapy: przed i po nawróceniu. W dalszej kolejności pojawia się relacja z życia osoby nawróconej: jest to życie zasadniczo odmienne od dawnego, szczęśliwsze i pełne głębokiego sensu. Jednostka definiuje swoje obecne życie głównie przez pryzmat nowo ustanowionej relacji z Bogiem, który staje się odtąd centralnym punktem odniesienia jej biografii ${ }^{26}$.

Na znaczenie procesu komunikowania dla rozstrzygnięcia, jakie zjawiska, doświadczenia czy działania mają charakter religijny, jakie zaś nie, zwraca uwagę Hans Joas podkreślając, iż doświadczenia transcendowania ludzkiej natury i przekraczania własnych ograniczeń (w różnym znaczeniu) są wspólne wszystkim ludziom, bez względu na to, czy są oni w swoich przekonaniach religijni, czy też nie. Można wymienić wiele przykładów takich doświadczeń: ekstatyczne poczucie zjednoczenia z całą naturą, doświadczenie wzajemnego zrozumienia między dwoma osobami, doświadczenie miłości czy wreszcie bezgranicznego zaangażowania w jakieś działanie. Różnica między nimi polega na sposobie ich wyrażania i interpretowania. To samo doświadczenie może być interpretowane w kategoriach religijnych lub nie ${ }^{27}$. Doświadczenia same w sobie nie mają więc jeszcze charakteru religijnego, zyskują go dopiero w procesie interpretacji poprzez komunikację. Tradycje i instytucje religijne stanowią w tym kontekście rezerwuary znaczeń umożliwiających interpretację doświadczeń transcendencji w sposób religijny poprzez powiązanie ich z rzeczywistością zewnętrzną wobec świata codziennych doświadczeń, to znaczy z Bogiem czy też Absolutem.

Założenia konstruktywistyczne koncentrują uwagę badacza na tym, w jaki sposób ludzie budują rzeczywistość społeczną, w której żyją i podejmują działania. W badaniach konstruktywistycznych rzeczywistość społeczna i zjawiska społeczne nie są traktowane jako zjawiska ,same w sobie”, to znaczy posiadające obiektywne cechy i obiektywnie istniejące, nie mogą więc być analizowane w oderwaniu od jednostek, które są ich twórcami. Badanie zjawisk religijnych może więc w takim

${ }^{26}$ B. Ulmer, Konversionserzählungen als rekonstruktive Gattung. Erzählerische Mittel und Strategien bei der Rekonstruktion eines Bekehrungserlebnisses, „Zeitschrift für Soziologie” 1988, nr 17, s. 19-33.

${ }^{27}$ H. Joas, Braucht der Mensch Religion? Über Erfahrungen der Selbsttranszendenz, Freiburg in Breisgau 2004, s. 22. 
ujęciu przyjmować za punkt wyjścia badanie komunikacji religijnej, aby za jej pośrednictwem zrozumieć, w jaki sposób religia definiuje samą siebie i wykryć kryteria decydujące o tym, które zjawiska i treści zostają w społeczeństwie uznane za religijne. Sławomir Mandes podsumowuje to następująco: „Jako naukowcy poszukujemy odpowiedzi na pytanie, czy u podłoża religijnej komunikacji leży jakaś organizująca ją w całość (system) i odróżniająca ją od otoczenia różnicująca zasada. Śledzimy trwałość tej różnicy, to, kiedy się pojawiła, w jaki sposób jest reprodukowana, jak motywuje ludzi do działania, w jakiej relacji pozostaje do innych systemów"28.

\section{PERSPEKTYWY ZASTOSOWANIA KONCEPCJI KOMUNIKACYJNO- -KONSTRUKTYWISTYCZNEJ W OBSZARZE SOCJOLOGII RELIGII ORAZ SOCJOLOGII DUCHOWOŚCI}

Teoria komunikacji stanowi jedną z bardziej obiecujących perspektyw w obszarze socjologii religii, a także zyskującej w ciągu ostatnich lat coraz większe uznanie socjologii duchowości. Niewątpliwą zaletą jej zastosowania w obrębie obu tych subdyscyplin może być rozszerzenie ich obszarów zainteresowań zarówno pod względem teoretycznym, jak i metodologicznym poprzez prowadzenie badań empirycznych uwzględniających potrzebę zrozumienia mechanizmów porozumiewania się, ich szczegółowy opis, wyjaśnienie z uwzględnieniem ich znaczenia zarówno dla porządku społecznego, jak i dla sfery religii. Socjologia religii dąży do adekwatnego opisu i wyjaśnienia współczesnych zjawisk religijnych oraz tych z pogranicza religii i duchowości, które można poznać za pośrednictwem istniejących już, ale również kształtujących się dopiero form komunikacji. Wrażliwość na te procesy pozwoli na ukazanie ich funkcji w odniesieniu do jednostek, wspólnot oraz instytucji religijnych i parareligijnych. Poszukiwanie odpowiedzi na pytanie, w jaki sposób poprzez porozumiewanie się ludzi powstaje definicja tego, co religijne, stanowi ważne zadanie dla badaczy współczesnych zjawisk religijnych.

Szczególne zainteresowanie w tej perspektywie mogą budzić formy komunikacji odbiegające znacząco od tych uznawanych za religijne, a jednak będące nośnikami treści „ostatecznych”. Perspektywa komunikacyjna pozwoli również rozpoznać formy, które przyjęło się określać jako religijne, choć w rzeczywistości z różnych względów nie spełniają one niekiedy funkcji nośnika treści religijnych ${ }^{29}$. Może dać

${ }^{28}$ S. Mandes, Miejsce religii w społeczeństwie, s. 325.

${ }^{29}$ Na przykład ze względu na trudności w ich rozumieniu wynikające z tego, że funkcjonowały pierwotnie w odmiennym kontekście historycznym i kulturowym. Patrz: M. Sokołowski, Kościół, kino, sacrum. W poszukiwaniu definicji filmów o tematyce religijnej, Olsztyn 2002, s. 16; G. Lohfink, Rozumieć Biblię: wprowadzenie do krytyki form literackich, Warszawa 1987. 
odpowiedź na pytanie, w jakich warunkach subiektywne doświadczenia nabierają cech „religijnych”, a w jakich zostają zaklasyfikowane do innych obszarów społecznej rzeczywistości, i na odwrót: jak musi wyglądać komunikacja religijna, żeby treści zobiektywizowane (intersubiektywne) funkcjonujące w obiegu społecznym zostały zinternalizowane przez jednostkę i rzeczywiście pełniły wobec niej funkcję orientacyjną, wpływającą na działania lub nawet je determinującą. Pozwoli dostrzec, w jaki sposób różne formy religii pełnią funkcję legitymizującą sens codziennych doświadczeń, ale również, jak powstają w tym kontekście substytuty, które mogą pełnić zbliżone funkcje, a nawet być odbierane przez jednostki i grupy jako ich własne, sprywatyzowane formy religijności. Może pomóc określić, jakie gatunki komunikacji są obecnie uznawane za religijne, ale również ukazać, w jaki sposób taka (pochopna często) klasyfikacja może utrudniać rozpoznawanie treści religijnych w „niereligijnych” gatunkach, co w sferze badań socjologicznych może na przykład prowadzić do pomijania form komunikacji, które nie są explicite religijne.

Analiza gatunków komunikacji w określonej społeczności dostarcza istotnych informacji na temat tego, jak dane środowisko funkcjonuje i w jaki sposób tworzy wspólny świat znaczeń. Chodzi tu o formy komunikowania uznane w danym środowisku, ale również o te, które pojawiają się, choć nie należą do „oficjalnego” repertuaru. Niektóre z nich mogą służyć utrwalaniu status quo, inne mogą transformować rzeczywistość społeczną lub nawet ją zmieniać. Można w ten sposób prześledzić również pojawiające się nowe tendencje w sferze religijności, poszukując chociażby odpowiedzi na pytania: jakie gatunki komunikacji cieszą się popularnością, bo odpowiadają na potrzeby religijne lub duchowe? Jakie powstają lub zanikają? Jakie są akceptowane, a jakie odrzucane? Może to stanowić istotną wskazówkę dotyczącą roli, jaką religijność i duchowość odgrywa w biografii jednostkowej oraz w życiu społecznym, a także tego, z jakimi sferami społecznej rzeczywistości jest powiązana, jakie funkcje oprócz religijnych może spełniać, czy pojawiają się jakieś ekwiwalenty pełniące funkcje niegdyś przypisywane religii. Obserwacja form komunikacji, ich wzajemnych powiązań w perspektywie synchronicznej, jak również obserwacja ich przemian w perspektywie diachronicznej, może pomóc dostrzec zmiany zachodzące w sferze religii i ich powiązania z konkretnymi zmianami kulturowymi. Pozwoli przez to być może w pełniejszy sposób zrozumieć, jaki sens człowiek współczesny przypisuje religii, na ile jest on zgodny z sensem komunikowanym przez instytucje religijne, a na ile taka komunikacja zachodzi w drugim obiegu, równolegle wobec komunikacji oficjalnej lub nawet w opozycji do niej.

Spełnienie tych postulatów przez komunikacyjne ujęcie religii nie będzie bynajmniej rzeczą łatwą, choćby z tego względu, że tendencje rozwojowe nowoczesnego społeczeństwa prowadzą do zacierania się granic między komunikacją religijną a innymi rodzajami komunikacji. Współczesna kultura popularna wpływa na formy kultu religijnego i vice versa: formy komunikacji religijnej pojawiają się w obszarach nie mających często nic wspólnego z religijną sferą instytucjonalną, na przykład w kontekście rozrywkowym, politycznym (religia cywilna) bądź w sferze 
poradnictwa psychologicznego i ruchów samopomocowych. Komunikacja w formie kojarzonej z religią zachodzi nie tylko w innych systemach symbolicznych, takich jak nauka czy sztuka, lecz przenika również do pewnych obszarów komunikacji codziennej. Nawet doświadczenie kontaktu z naturą, doświadczenie ciała czy wspólnoty może być również komunikowane w sposób, który nasuwa skojarzenia z komunikacja religijną ${ }^{30}$.

Takie tendencje rozwojowe sprawiają, że ważnym zadaniem współczesnej socjologii religii będzie odkrywanie elementów religijnych lub mających swoje źródła w religii tam, gdzie na pierwszy rzut oka nie są one zauważalne. Wymagać to będzie dużej wrażliwości badawczej, a także prawdopodobnie bardziej niż dotychczas wyspecjalizowanych metod badawczych, bardziej jakościowych niż ilościowych. Obszar zainteresowań badawczych socjologów religii poszerza się, ale jednocześnie staje się nieoczywisty, niejednoznaczny, wymagający interpretacji, których obiektywna wartość będzie musiała być dopiero sprawdzona. Nadzieję na wykształcenie takiego oglądu sfery zjawisk religijnych daje komunikacyjna perspektywa socjologii religii.

\section{BIBLIOGRAFIA}

Berger P. L., Luckmann T., Społeczne tworzenie rzeczywistości. Traktat z socjologii wiedzy, Warszawa 2010.

Campbell J., Potęga mitu. Rozmowy Billa Moyersa z Josephem Campbellem, Kraków 2007.

Garfinkel H., Studia z etnometodologii, przeł. A. Szulżycka, Warszawa 2007.

Habermas J., Pojęcie działania komunikacyjnego, „Kultura i Społeczeństwo” 1986, nr 3, s. 21-44.

Hanegraaff W. J., New Age Religion and Western Culture: Esotericism in the Mirror of Secular Thought, Leiden 1996.

Huntington S. P., Zderzenie cywilizacji i nowy kształt ładu światowego, przeł. H. Jankowska, Kraków 1997.

Joas H., Braucht der Mensch Religion? Über Erfahrungen der Selbsttranszendenz, Freiburg in Breisgau 2004.

Knoblauch H., Grundbegriffe und Aufgaben des kommunikativen Konstruktivismus, Manuskriptfassung des Textes in: R. Keller, H. Knoblauch, J. Reichertz (Hg.), Kommunikativer Konstruktivismus. Theoretische und empirische Arbeiten zu einem neuen wissenssoziologischen Ansatz, Wiesbaden, s. 25-48.

Knoblauch H., Religionssoziologie, Berlin - New York 1999.

Knoblauch H., Schnettler B., Vom sinnhaften Aufbau zur kommunikativen Konstruktion, in: M. Gabriel (Hg.), Paradigmen akteurszentrierter Soziologie, Wiesbaden 2004, s. 121-136.

${ }^{30}$ J. Mariański, S. A. Wargacki, Nowa duchowość jako megatrend społeczny i kulturowy, „Przegląd Religioznawczy” 2011, nr 4, s. 138; W. J. Hanegraaff, New Age Religion and Western Culture: Esotericism in the Mirror of Secular Thought, Leiden 1996, s. 116 n.; K. T. Konecki, „Ciało świątynią duszy”, czyli o procesie budowania tożsamości praktykującego hatha-jogę. Konstruowanie prywatnej quasi-religii, „Przegląd Socjologii Jakościowej” 2012, nr 2, s. 109. 
Knoblauch H., Transzendenzerfahrung und symbolische Kommunikation. Die phänomenologisch orientierte Soziologie und die kommunikative Konstruktion der Religion, w: H. Tyrell, V. Krech, H. Knoblauch (Hg.), Religion als Kommunikation, Würzburg 1998, s. 147-186.

Konecki K. T., „Ciało świątynią duszy”, czyli o procesie budowania tożsamości praktykującego hatha-jogę. Konstruowanie prywatnej quasi-religii, „Przegląd Socjologii Jakościowej” 2012, nr 2, s. 64-111.

Küng H., Projekt Weltethos, München 1990.

Lohfink G., Rozumieć Biblię: wprowadzenie do krytyki form literackich, Warszawa 1987.

Luckmann T., Der kommunikative Aufbau der sozialen Welt und die Sozialwissenschaften, w: tenże, Wissen und Gesellschaft. Ausgewählte Aufsätze 1981-2002, Konstanz 2002, s. 157-182.

Luckmann T., Niewidzialna religia. Problem religii w nowoczesnym społeczeństwie, przeł. L. Bluszcz, Kraków 2011.

Luckmann T., Über die Funktion der Religion, w: P. Koslowski (Hg.), Die religiöse Dimension der Gesellschaft. Religion und ihre Theorien, Tübingen 1985, s. 26-41.

Luhmann N., Die Gesellschaft der Gesellschaft, Frankfurt am Main 1999.

Luhmann N., Vom Sinn religiöser Kommunikation, w: K. Gabriel, A. Herlth, K. P. Strohmeier, Modernität und Solidarität. Konsequenzen gesellschaftlicher Modernisierung. Für Franz-Xaver Kaufmann, Freiburg in Breisgau 1997, s. 163-174.

Mandes S., Miejsce religii w społeczeństwie. W poszukiwaniu nowego programu badawczego socjologii religii, Warszawa 2016.

Mariański J., Megatrendy religijne w społeczeństwach ponowoczesnych. Studium socjologiczne, Toruń 2016.

Mariański J., Wargacki S. A., Nowa duchowość jako megatrend społeczny i kulturowy, „Przegląd Religioznawczy" 2011, nr 4, s. 135-158.

Matthes J., Handlungstheoretisch - interaktionistisch - phänomenologisch orientierte Theorie, w: R. Lepsius (Hg.), Zwischenbilanz der Soziologie, Stuttgart 1976, s. 53-59.

Mörth I., Die gesellschaftliche Wirklichkeit von Religion. Grundlegung einer allgemeinen Religionstheorie, Stuttgart 1978.

Schütz A., Der sinnhafte Aufbau der sozialen Welt, Wien 1960.

Schütz A., Symbol, Wirklichkeit und Gesellschaft, w: tenże, Gesammelte Aufsätze, Band 1: Das Problem der sozialen Wirklichkeit, Den Haag: Nijhoff 1971, s. 331-414.

Schütz A., Über die mannigfaltigen Wirklichkeiten, w: Gesammelte Aufsätze Bd. 1, den Haag 1971, s. 237-298.

Sokołowski M., Kościół, kino, sacrum. W poszukiwaniu definicji filmów o tematyce religijnej, Olsztyn 2002.

Ulmer B., Konversionserzählungen als rekonstruktive Gattung. Erzählerische Mittel und Strategien bei der Rekonstruktion eines Bekehrungserlebnisses, „Zeitschrift für Soziologie” 1988, nr 17, s. 19-33.

Watzlawick P., Beavin J., Jackson D. D., Pragmatics of human communication, New York 1967.

\section{Streszczenie}

Artykuł przedstawia główne wątki myśli socjologicznej i filozoficznej, które przyczyniły się do powstania orientacji komunikacyjnej w socjologii religii. Stanowi ona, zdaniem wielu socjologów, nową perspektywę umożliwiającą opis i wyjaśnianie współczesnych form, w jakich manifestuje się religia, a także szerokiego spektrum zjawisk z dziedziny nowej duchowości. Obserwacja form komunikowania może pomóc dostrzec zmiany zachodzące $w$ sferze religii oraz ich powiązanie z konkretnymi zmianami kulturowymi. 
Autorka prezentuje koncepcje socjologiczne i filozoficzne, w których podejmowana była tematyka sensu i jego komunikowania: od socjologii rozumiejącej M. Webera poprzez socjologię fenomenologiczną, społeczny konstruktywizm, koncepcję komunikacji N. Luhmanna, aż po współczesne koncepcje socjologiczne, które zaliczyć można do nurtu konstruktywizmu komunikacyjnego. Podejmuje również refleksję nad możliwościami zastosowania koncepcji komunikacyjnej w obszarze socjologii religii i socjologii duchowości.

Słowa kluczowe: religia, duchowość, teoria komunikacji, sens, konstruktywizm socjologiczny.

\title{
PHENOMENOLOGICAL AND CONSTRUCTIVIST ASSUMPTIONS AS THE BASIS OF COMMUNICATION THEORY IN SOCIOLOGY OF RELIGION.
}

\begin{abstract}
Sum mary
The paper presents main themes of sociological and philosophical thought which contributed to establishment of communicative orientation in sociology of religion. According to numerous sociologists, it constitutes a new perspective providing an explanation and description of contemporary forms in which religion is manifested, and also a broad spectrum of phenomena in the field of spirituality. Observation of forms of communication may help to notice changes in the sphere of religion as well as their connection with particular cultural changes.

The author presents sociological and philosophical conceptions in which the subject of sense and its communication is taken up; from interpretive sociology by M. Weber, phenomenological sociology, social constructivism, conception of communication by N. Luhmann through contemporary sociological conceptions that may be included in a current of communicative constructivism. The author reflects on possibilities of applying the communicative conception in the field of sociology of religion and sociology of spirituality.
\end{abstract}

Key words: Religion, spirituality, theory of communication, sense, sociological constructivism. 


\section{STUDIA PODYPLOMOWE NA UCZELNIACH TECHNICZNYCH - DOSTOSOWANIE OFERTY EDUKACYJNEJ DO POTRZEB RYNKU PRACY}

\section{STUDIA PODYPLOMOWE JAKO FORMA KSZTAŁCENIA}

Studia podyplomowe jako forma kształcenia w ramach tradycyjnego podejścia należą do systemu edukacji formalnej, gdyż ich profil związany jest z regularną formą nauki, prowadzoną przez uprawnione do nauczania instytucje edukacyjne (przede wszystkim szkoły wyższe), a zajęcia odbywają się zgodnie z zatwierdzonymi programami nauczania. Ramy prawne dla studiów podyplomowych ustanowione są w Ustawie o szkolnictwie wyższym¹.

Jednakże w praktyce, zgodnie z wynikami badań uczestników tej formy kształcenia, jednym z ważnych motywów podejmowania studiów podyplomowych (podobnie jak studiów MBA - Master of Business Administration) jest nawiązywania relacji pozaformalnych, nawiązywanie kontaktów biznesowych i zdobywanie doświadczenia w wyniku rozmów z innymi uczestnikami studiów (networking)2 Biorąc powyższe trzeba zauważyć, że studia podyplomowe nie mieszczą się w ramach klasyfikacji jako kształcenie stricte formalne.

W chwili obecnej w Polsce nie funkcjonuje uregulowany prawnie system, w ramach którego można potwierdzać kwalifikacje zawodowe uzyskane na drodze pozaformalnej. Sejm VIII kadencji, w grudniu 2015 roku przyjął ustawę, która wprowadzi stosowne i jednoznaczne uregulowania m. in poprzez uruchomienie Zintegrowanego Rejestru Kwalifikacji. Konsekwencją tego będzie umiejscowienie systemu kształcenia nieformalnego i pozaformalnego w ramach systemu formalnego.

\footnotetext{
* Dr BARtosz SobotKa - Syntea SA, Lublin, e-mail: bartosz.sobotka@syntea.pl.

${ }^{1}$ Ustawa z dnia 27 lipca 2005 r. - Prawo o szkolnictwie wyższym; Dz.U. nr 164, poz. 1365 z późn. zm.

${ }^{2}$ I. Janiak-Rejno, Kształcenie ustawiczne słuchaczy studiów podyplomowych - wyniki badań empirycznych, „Edukacja ustawiczna dorosłych” 2009, nr 4(67), s. 50-57. http://www.mttp.pl/pobieranie/badanie_thinktank_mba.pdf; (dostęp 15.05.2016).
} 